\title{
Key factors influencing family businesses: qualitative study of selected world wineries
}

\author{
Vojtěch Koráb \\ Faculty of Business and Management, Brno University of Technology, Czech Republic
}

\begin{abstract}
This research study is based on the elaboration of nineteen case studies of family wineries from all over the world and one case study from the Czech Republic. All family wineries were visited by the author and semi-structured interviews were conducted with selected representatives of family wineries. The aim of the research was to look at the family winery through the lens of two systems: the family system and the business system, in order to find out the involvement of family members in a winery and the most important factors affecting a winery. Websites of family wineries were examined through contextual analysis. Based on the analysis of all case studies, four key groups of family wineries in the world were compiled. The research study identifies key family factors, i.e. familiness and the generation of the family which owns a winery. On the business side, the study identifies two key factors important for the sustainability of a family winery, namely corporate innovation and the degree of internationalization. The results of the analysis of world family wineries were compared with one winery selected from the Czech Republic.
\end{abstract}

\section{Introduction}

The history of family businesses is connected with the entire modern history of mankind. The oldest family business still in operation is the Japanese business hotel Hoshi Ryokan. This family business was founded as early as 718 . The oldest family businesses are not concentrated in only one business sector, but their activities are spread over different business sectors. It is very gratifying that there are six companies operating in the wine sector in the top twenty oldest family businesses in the world. We can say that in most of the world's economies, the role and importance of family businesses is absolutely crucial. It can be estimated that family businesses account for approximately $70-90 \%$ of the world's wealth. The business sector in which family businesses play a key role is the agricultural and wine sectors. Family businesses in these sectors predominate, especially in the category of micro and small businesses. Family businesses are understood as synergies between two systems - the family system and the business system. In the family system, it is important to identify the family's involvement in the family business and to identify the generation that currently controls (owns and manages) the family business. In the business system, it is crucial to characterize the innovative activities of the family business and the degree of internationalization of the family business. The family wineries were analysed through this lens, and research questions are also based on this lens. This article deals with the analysis of selected wineries in the world. These family wineries are processed in the form of research case studies. These case studies were subsequently analysed and research results were discussed. The aim of the research was to perform an analysis of selected world family wineries. A partial goal was to compare the results of this analysis with selected family wineries in the Czech Republic.

\subsection{Family business definition}

The definition of a family business is quite widely discussed in academic literature. Family businesses are presented as entities involving family members involved in business [1], [2], [3] through ownership and control, involvement in business management and wishing to pass the business to the next generation in the future [4]. In these definitions, the business system is permeated by another system, namely the family system. These two systems are often referred to as the two-circle model. It is argued that this interconnection of the two systems imposes special requirements on the family and that the family must manage both family and business requirements so that neither the family nor the business is endangered. Most research and theoretical work on family business, which elaborates on family theory, uses systems theory [5] to assess how business and family systems relate to each other. Authors Sharma and Nordqvist [6] provide an overview of the development of this theory in family business academic literature. New frameworks include the theory of new systems. In academic papers 
this theory is sometimes called the "three-circle model", as well as the "open systems approach", "family ecosystems" and a "view of resources". However, these new theories will not be discussed further in the article, as they go beyond its scope. Based on the above characteristics of two systems, the family system and the enterprise system, we can give the following definition of a family enterprise: "a family enterprise is an enterprise owned or managed by a family/families or selected family members, it is assumed that the company will be passed on to the next generation ". The definition affects entrepreneurs, such as registered farmers and winegrowers, but also legal entities, i.e. businesses. It also preserves the basic attribute of family businesses, i.e. the transfer of the business to the next generation. This definition was used to examine global family wineries in this study. However, this definition does not cover family ties. These family ties are described by the family, which will be introduced below.

\subsection{Familiness}

Familiness is an important factor in understanding the functioning of family businesses [7], [8], [9], [10]. Familiness refers to the nature of the family relationship in the enterprise [11], family kinship and subsequent resources and abilities, unique to the involvement of family members in the family enterprise [12], [13]. All this characterizes the influence of the family on the family business [14]. Wilson and Tonner [15] define "familiness" as a resource that gives a business a competitive advantage. Key activities provide family members with space to negotiate their positions within the family. The study of these authors shows that family businesses benefit from wider networks and the strong and weak ties of individual family members.

\subsubsection{Involvement of family members in the company}

Family kinship characterizes the affinity of those family members who are involved in the control of the family business. Family kinship of family members can be quite complex. Some links can be quite distant. The academic literature lacks a deeper analysis of the differences in the structure of family relationships, i.e. the genetic links of family members holding leadership positions in the company. The study [16] captures the degree of closeness of family kinship between family managers and explains why family behaviours and motives with close relatives and distant relatives have different priorities. Research shows that various forms of family involvement in the business, for example through share ownership, board presence and management positions, have an impact on the family's influence on the family business's strategic decisions. The extent and complexity of family kinship of family members involved in a family business makes it difficult to identify family businesses and include them in a research sample.

\subsection{The family generation currently holding power in family businesses}

As follows from the above definition of a family business, the family strives to maintain power in the business in the future and pass on power and ownership to the next generation. When examining the family kinship of family members who are involved in the management and control of a family business, it is also necessary to examine which generation currently holds power in the family business, i.e. in which generation the family business is located. Many research studies speak of the socio-emotional wealth created by family businesses owned by the family for several generations. These studies are also focused on the wine sector. The authors Fernandez-Olmos, Diaz-Vial and Malorgio [17] state that the last generation of the family who controls the family business has a higher socio-emotional wealth and this affects the overall performance of the business. The authors Delmans and Olivier [18] point out that the focus on the future generation of the family, measured as the intention of the winery owner to pass the winery on to his children, is associated with the adoption of sustainable development of the family winery.

\subsection{Innovation in family businesses}

Innovation is seen as an improvement. Innovation is a complex process from the initial idea, through development to eventual implementation. Thus, innovation is more than creativity or invention, which, while a necessary part of innovation, brings new ideas, but is not in itself sufficient to fulfil innovation. Many new ideas do not lead to innovations because they are not feasible (from a technical, practical or economic point of view). The result of innovation is an improved process, product, service, or anything else. A distinction is usually made between product or service innovation, process innovation, organizational innovation and marketing innovation. It is important for wine family businesses that their innovation strategy is linked to the tradition of the family business. It is a combination that can give a family winery a 
competitive advantage in the wine market [19]. The literature shows that the impact of product and process innovation in the family business on consumer perception is crucial [20]. In wine consumption, cultural identity among customers is associated with a broader desire for authentic experiences. Research studies further show that customers value local products if they embody the tradition, heritage, culture, ethnic diversity and identity of a particular place [21]. A good brand is essential in the wine sector, and its importance is growing, especially in those well-known wineries operating in top markets [22].

\subsection{Internationalization of family businesses}

The internationalization of a company is an important factor in the sustainability of a family business. The internationalization of a family business is directed both inside the company (internationalization of products, people, systems and management of the family business) and outside the company (the ability of the family business to carry out marketing, banking and business international operations). A study by Zhou, Han and Gou [23] states that family ownership and management of a family business has a positive effect on the depth and breadth of internationalization of the family business. Furthermore, the environmental generosity of the family business, on the other hand, weakens the effect of family ownership on the depth of internationalization. The research questions that were set for the research study stem from the understanding of the family business as the intersection of two systems, namely the family system and the business system. Understanding two basic problems is key to the family system. Firstly, the involvement of family members in the management of the family business and the determination of the family generation, and secondly, which generation currently controls (owns and manages) the family business. An understanding of the degree of innovation in the family business and the degree of internationalization of the family business is crucial for the business system. The following are the research questions:

VO1: How are family members involved in the control of a family wine business?

VO2: In which generation of the family is the family wine business currently located?

VO3: What innovations does the family wine business apply in practice?

VO4: How is the family wine business internationalized?

\section{Methods}

\subsection{Selection sample}

From 2005 to 2018, the author visited 58 wineries around the world as part of his wine tours. Of these wineries, 31 wineries were identified as family wineries. Due to the limited time to conduct an interview with the winery's representatives during the visit of the winery, some of the interviews were incomplete and these wineries had to be excluded from the basic sample. Finally, 19 family wineries from around the world and one winery in the Czech Republic were included in the sample. These family wineries meet the definition of a family business presented above. All wineries included in the sample were understood as research case studies. The sample included one family winery from Africa (South Africa), two wineries from South America (Chile, Argentina), two from North America (USA, California), two from Asia and Oceania (Australia and New Zealand) and 12 wineries from Europe (France, Italy, Spain, Portugal, Germany, Austria and Switzerland). Apart from one family winery from the Czech Republic, no family wine businesses from Eastern Europe were examined.

\section{2 Methodology used}

The methodology applied in this research arose from the understanding of the family business through the lens of two systems, the family system and the business system. Primary and secondary data collection methods were used. For a maximum understanding of the behaviour of individual family wineries, techniques of collecting qualitative data by the method of semistructured interviews were applied when visiting these wineries. In identifying family wineries, the websites of family businesses were also examined. The method of contextual analysis was used in the analysis of the family wineries' websites. In the analysis of the first stage, the fullness of the definition of a family business and the nature of family viticulture were examined. In the analysis of the second stage, semi-structured interviews with selected representatives of family wineries captured on voice recorder and video camera were analysed. The interviews were converted into electronic form. Manual literal transcription and coding were used to analyse these interviews. 


\section{Results}

\subsection{First degree analysis}

In this analysis, the fulfilment of the definition of a family business was assessed and the characteristics of the family winery were studied from the point of view of the size of the family business and the degree of involvement of the family winery in cooperation groups. From the point of view of the size of the family business and the degree of involvement in cooperation groups, family wineries were classified into four clusters, which are shown in Figure 1.

\begin{tabular}{|l|l|l|l|}
\hline \multirow{2}{*}{ Wine family businesses } & \multicolumn{2}{|c|}{ The size of a family winery } \\
\cline { 3 - 4 } & \multicolumn{2}{|c|}{ Small } & \multicolumn{2}{|c|}{ Big } \\
\hline \multirow{2}{*}{$\begin{array}{l}\text { Degree of } \\
\text { dependence } \\
\text { of } \\
\text { family wine } \\
\text { business on } \\
\text { other } \\
\text { wineries }\end{array}$} & Small & $\begin{array}{l}\text { Cluster I. Small, } \\
\text { independent family } \\
\text { winemakers }\end{array}$ & $\begin{array}{l}\text { Cluster II. Big, } \\
\text { independent family } \\
\text { winemakers }\end{array}$ \\
\cline { 2 - 4 } & Big & $\begin{array}{l}\text { Cluster III. Small } \\
\text { associations of family } \\
\text { winegrowing enterprises }\end{array}$ & $\begin{array}{l}\text { Cluster IV. Big joint } \\
\text { ventures, } \\
\text { big associations of } \\
\text { family wine enterprises }\end{array}$ \\
\hline
\end{tabular}

Fig. 1 Classification of family wineries into four clusters

Individual clusters of family wineries, including the number of wineries in the cluster, can be characterized as follows:

Cluster I. Small independent family winemakers (nine family wineries). These winemakers grow grapes and also produce wine. They produce wine mostly for the needs of their family and for sale. These are winemakers who produce wine not as a hobby, but produce it on a professional level as their main business.

Cluster II. Big, independent wine family players (six family wineries). These family businesses determine the price of the grapes and the price of the wine on the market. These family wineries also determine the global quality of wine.

Cluster III. Small, cooperative association of family wineries (one group of family wineries). These are family grape growers. These growers are then members of wine cooperatives. Family winemakers supply grapes to wine cooperatives, but also produce a small amount of wine for their own use. Family wineries included in this cluster are identifiable especially in France.

Cluster IV. Big, joint ventures, large groupings of family wineries (three large groupings of family wineries). These are joint ventures of big players from different countries, which form a joint venture in a third country, or even an alliance of large wine companies in their own country.

Although the division of family wineries into individual clusters is uneven, family wineries predominate in Cluster I and in Cluster II, these results of the first degree analysis can be understood as very useful and as a possible future direction of research in the field of family wineries.

\subsection{Second degree analysis}

\subsubsection{Involvement of family members into the family business, determination of family} kinship

The analysis of semi-structured interviews of selected members of family wineries identified three family ties which are significant:

Family kinship 1: husband-wife - this link can be called a horizontal kinship. From the point of view of the above definition of a family wine enterprise, this includes a partner-partner family kinship.

Family kinship 2: parents-children - we can call this link horizontal/vertical. It is also possible to include the ties of one parent-more than one child, or one of the parents-one of the children. 
Family kinship 3: parents/children-grandparents - we can call this link a purely vertical link. One of the grandparents also works in the family winery, but mostly only as a consultant.

The results of the second-level analysis in the area of family members' involvement in the management of the family business show the involvement of the closest family members. Efforts to involve more distant relatives in the management of the family business have not been identified. These results could also be compared with the results of a research study in the Czech Republic [24], where the involvement of family members in the management of family wineries is similar.

\subsubsection{The family generation currently holding power in family businesses}

Clusters of family wineries show the control of a family business by the following generations of the family:

Cluster I: Here are nine small, independent family wineries. In this cluster, three family wineries were controlled by one generation of the family, one family winery controlled by three generations of the family, one family winery controlled by four generations of the family, four family wineries controlled by five generations of the family. The characteristics of family wineries in this cluster show that family wineries do not necessarily grow in their development. It is obvious that a family winery can maintain a small size and with a well-established sustainability live to longevity.

Cluster II: Six large independent family wineries are included here. In this cluster there were two family wineries controlled by five generations of the family, three family wineries controlled by six generations of the family and one family winery controlled by seven generations of the family. These wineries were not only very well managed (the family businesses grew), but the family also successfully managed to hand over power to the next generations, and the family winery was thus preserved in the family for generations.

Cluster III: Included here is one group of small family wine companies, which has the character of a cooperative. The generation of the family could not be determined during an interview with a representative of the wine group. It can only be inferred that since the wine cooperative was founded in 1930, there has now been three generations of micro-family businesses growing grapes and supplying them to the wine group. At present, 280 micro family businesses are involved in the wine group. This grouping of family businesses was observed only for family businesses in France. In other countries, these efforts to form cooperation groups have not been observed.

Cluster IV: This includes three large family wine businesses involved in international groupings. In this cluster, there was one family winery controlled by two generations of the family, one family winery controlled by three generations of the family and one family winery controlled by one family ever since its establishment in 1041. In this winery, the winery answered a question about which family generation controls the company controls: "We do not count the family generation here due to the history of the family". This is an Italian family winery, which is one of the oldest family wineries in the world. Family wineries, in an effort to expand into foreign wine markets, form large international alliances, are able to produce large volumes of wines of global quality and produce wines to the average consumer's tastes in global markets.

\subsubsection{Innovation activities of family businesses}

Innovative activities in the world's family wineries have been applied in the following areas:

Product innovation. Family wineries around the world are based on a family tradition, which is built on family values. Family wineries pay great attention to the quality of wines and the loyalty of their customers. There was not much effort in the wineries to introduce new wines, such as rosé wine, or the production of wines in clay containers called „kvevri“. Efforts to innovate of this type have not been analysed in any of the clusters of family wineries. Large family businesses, included in Cluster II, produce wines from global vine varieties, such as Cabernet Sauvignon, Merlot, Pinot Noir, Malbec, Zinfandel, Tannat, Carmenere, Pinotage, Siraz, Sauvignon Blanc, Riesling, Chardonnay, or Traminer. For small family wineries included in Cluster I, the cultivation of so-called autochthonous vine varieties (vines that occur only in a given wine-growing area) and the production of wines from them were analysed.

Innovations in wine technologies. Family wineries in all clusters use advanced winemaking technology to produce wine. Pneumatic presses are commonly used for wine production, which gently press the juice from the grapes and the controlled fermentation of the juice in stainless steel tanks. Wooden barrique barrels of the French or Slavonian type are used for wine maturing. Only in South African winery were efforts analysed to use French wooden oak boards instead of wooden barrels, which were lowered in a controlled manner into stainless 
steel tanks. Efforts for a gentle wine production process at family businesses in all clusters were analysed. Sulphur was used to a minimal extent. The process of so-called malolactic fermentation (the process of degrading malic acid and conversion to lactic acid) was also used in small family wineries.

Innovation in vineyards. Strong efforts to invest in vineyards was analysed for all the world's family wine businesses. Efforts to protect vineyards from spring frosts have been identified in family wineries located in northern areas. The vineyards are warmed during these frosts to prevent the vines from freezing. Family businesses in all clusters were characterized by ecologically approached vineyard management. Here is a typical statement of one representative of a family winery: "Our philosophy is based on respecting the unique conditions of the environment where we grow vines. Why not respect our soil? Why not respect natural conditions? Our approach is a biological approach to farming in our vineyards." Family wine businesses in all clusters were characterized by a friendly ecological approach to farming in the vineyards. A very nice example of a nice environment combined with a clever approach to vine growing was identified in California. The surprise was a chicken coop on wheels, which transported hens to the vineyard. The hens in the vineyard were picking pests between the rows of vines. Sheep were also transported to the vineyards, grazing on grass between the rows in the vineyards. So-called biodynamic management was also recorded in small family wine-growing enterprises (individual work on the vineyards was carried out with respect to the phases of the moon). Large investments were identified in large wineries, which led to the energy self-sufficiency of the family winery and the so-called zero carbon footprint.

Innovation in the wine trade. A common attribute of all family wineries analysed was a strong effort for international visibility. All the family wineries have tried to succeed in prestigious international wine competitions. The awards from these competitions were then used by wineries as a tool shop. For large family wineries included in Cluster II, a robust eshop capable of sending wines worldwide was identified. In this context, very strong innovation activities in etiquette innovation were identified. Each bottle of wine has a label. Family wineries understand etiquette as the customer's first contact not only with wine, but also with family wineries. Great attention is paid to the design of etiquettes in family wineries. Many family wineries work with renowned designers and artists to design etiquettes and do not hesitate to invest significant resources in etiquette design.

\subsubsection{Internationalization of family businesses}

The internationalization of the world's wine family businesses showed a focus both inside and outside the wine family business. Wine family businesses of all clusters are open to international clients. The ability to present their wines and tour the winery in English was found everywhere. The family wineries had the capacity of their employees to prepare selected wines for international wine competitions. Family wineries have carefully maintained their websites in several languages, but at least in their home language and in English. Even the family businesses of Cluster I had an effective online e-shop, and were able to deliver wines to their own country, in selected cases throughout Europe. Family businesses of Clusters II., III. and IV were able to send wines around the world.

\section{Discussion}

When comparing the most important conclusions of the qualitative analysis of 19 selected global family wineries with a selected family winery from the Czech Republic, it is possible to state the following differences:

\subsection{First degree analysis}

After classifying selected world family wineries, it can be stated that most family wineries are located in Cluster I. - small independent family businesses and Cluster II - big independent family businesses. Also a small Czech family wine business can be included in Cluster I.

\subsection{Second degree analysis}

\subsubsection{Involvement of family members in the family business, determination of family kinship}

Family wineries around the world are built on a very strong intergenerational business of other family members. Three types of family kinships have been identified in the world's family wineries: horizontal, horizontal/vertical and vertical. Even in the case of a Czech family wine enterprise, a horizontal/vertical family connection can be identified. The family business is based on a stable family with historical traditions. The family relies on traditional Christian values. It is possible to give an excerpt from an interview with the owner of a family winery: "Since our establishment, we have been a family business, literally and figuratively. Božena's 
wife takes care of almost everything and everyone. Our daughter Božena became the Czech Queen of Wine in 2001 and in 2003 she and her husband opened our store in České Budějovice. His son Josef has been involved in the running of the company since his early youth and is a capable assistant in foreign trade and travel. His brother František takes care of the vineyards with his whole family, so we have the highest quality grapes", said its owner about his winery.

\subsubsection{The family generation currently holding power in family businesses}

Most of the world's family wineries have identified a higher generation of the family that currently controls the family business. Exceptions were three family wineries included in Cluster I. In addition, the Czech family winery can be included in Cluster I. The company was founded in the 1990s after the velvet revolution (1989). Based on the analysis of the Czech family winery, it is possible to state that it also relies on a deep family tradition and this tradition is often boasted of. Although the family's genealogical tree is not displayed in the wine tasting room, but the family winery wants to keep the family business in the family and pass it on to the next generation.

\subsubsection{Innovation activities of family businesses}

In selected global family wineries, innovation activities were analysed in four areas: Innovation in products, innovation in technology, innovation in vineyards and innovation in trade.

Innovation in products. For big global wine family businesses in Cluster II a great effort in product innovation has not been analysed. The winery grew global grape varieties. The effort of growing autochthonous vine varieties was also analysed in small family wine businesses in Cluster I. The Czech family wine business went its own way from the beginning of the business and always let the wines mature. The winemaker likes to experiment with the production of a mixture of wines or unusual processing of vine varieties. He tested new vine varieties in the vineyard, and was among the first winemakers in the Czech Republic to plant, for example, the Merlot, Cabernet Franc, Cabernet Blanc, Carmenere and Lena varieties.

Innovation in technology. Family wineries around the world are built on modern technologies. A very strong effort towards innovation was seen in the wineries. Families have a very strong relationship with the land and try to approach the land in a very gentle, ecological way. The world's wineries have also seen an effort to invest in seemingly unrelated areas. In many wineries, small wine museums were built. In larger wineries you could also see investments in art, both in paintings and in sculptures and other art. The Czech wine family business is equipped with the same modern technologies as seen throughout in the world.

Innovation in vineyards. The vineyards at the world's wineries are very heavily invested in climate protection, spring frost damage and bird damage. At the Czech wine family business, a strong relationship of family members to the land was identified, as in family wineries across the world. However, its vineyards are not as heavily invested as in wineries around the world.

Innovation in the wine trade. The world's family wineries in all clusters pay great attention to innovations in the wine trade. They have great efforts for international visibility. Strong efforts have been identified to succeed in prestigious international world wine competitions and efforts to sell wines on international markets. Also, the effort to succeed in international world wine competitions can be analysed at the Czech family winery. The Czech family winery has won a number of awards abroad. Recently we can mention, for example, big gold and gold medals from the global competitions Concours Mondial de Bruxelles, Concours International des Vins Lyon or Ice Wine du Monde. The biggest foreign success is the overall third place out of almost a thousand samples at the world competition Chardonnay du Monde 2011, supported by repeated placement in the Top 10.

\subsubsection{Internationalisation of family businesses}

Two dimensions of internationalisation have been identified in the world's family wineries, namely the internal dimension and the external dimension. The internal dimension was the internationalisation of the internal environment of viticulture, including the internationalisation of the product, i.e. wine. The external dimension was a particularly powerful e-shop capable of sending wines to the whole world. At the Czech winery, the wines were supplied mainly to the Czech market. Due to its wine production, the winery is not able to satisfy the demand from abroad in larger quantities. Smaller deliveries of wines abroad thus serve more to maintain the prestige of the winery and international awareness of the wines of this Czech winery. 


\section{References}

1. Anderson, A.R., Jack, S.L., Dodd, S.D., The role of family members in entrepreneurial networks: beyond the boundaries of the family firm. Family Business Review, 18, 135-154 (2005)

2. Upton, N., Petty, W., Venture capital investment and US family business. Venture Capital, 2, 39 (2000)

3. Whiteside, M.F., Brown, F.H., Drawbacks of a dual systems approach to family firms: can we expand our thinking? Family Business Review, 4, 383-395 (1991)

4. Chua, J.H., Chrisman, J.J., Sharma, P., Defining the family business by behavior. Enterpreneurship Theory and Practice. 23, 19-19 (1999)

5. Jennings, J.E., Breitkreuz, R.S., James, A.E., Theories from family science: a review and roadmap for family business research. In: Melin, L., Nordqvist, M., Sharma, P. (Eds.), SAGE Handbook of Family Business. Sage, London, 25-46 (2014)

6. Sharma, P., Nordqvist, M., A classification scheme for family firms: from family values to effective governance to firm performance. In: Tapies, J., Ward, J. (Eds.), Family Values and Value Creation: the Fostering of Enduring Values within Family- Owned Businesses. Palgrave Macmillan, New York, 71-101 (2008)

7. Chrisman, J.J., Chua, J.H., Litz, R., A unified systems perspective of family firm performance: an extension and integration. Journal of Business Venturing. 18, 467-472 (2003) 8. Habbershon, T.G., Williams, M.L., A resource-based framework for assessing the strategic advantages of family firms. Family Business Review, 12, 1-25 (1999)

9. Nordqvist, M., Sharma, P., Chirico, F., Family firm heterogeneity and governance: a configuration approach. Journal of Small Business Management, 52, 192-209 (2014)

10. Zachary, R.K., The importance of the family system in family business. Journal of Family Business Management, 1, 26-36 (2011)

11. Habbershon, T.G., Williams, M., MacMillan, I.C., A unified systems perspective of family firm performance. Journal of Business Venturing, 18, 451-465 (2003)

12. Pearson, A.W., Carr, J.C., Shaw, J.C., Toward a theory of familiness: a social capital perspective. Enterpreneuship Theory and Practice, 32, 949-969 (2008)

13. Rautiainen, M., Pihkala, T., Ikävalko, M., Family business system models: a case study and some implications of open systems perspective. Journal of Small Business and Enterpreneurhip, 25, 155-168 (2012)

14. Zellweger, T.M., Nason, R.S., Nordqvist, M., Brush, C.G., Why do family firms strive for nonfinancial goals? An organizational identity perspective. Enterpreneurship. Theory and Practice, 37, 229-248 (2013)

15. Wilson, J., Tonner, A. Doing family: The constructed meanings of family in family farms. Journal of Rural Studies, 78, 245-253 (2020)

16. Yu, X., Stanley, L., Li, Y.,Eddleston K.A., Kellermans, F.W., The invisible hand of evolutionary psychology: The importance kinship in first-generation family firms. Entrepreneurship Theory and Practice. 44, 134-157 (2020)

17. Fernadez-Olmos, M., Diaz-Vial, I., Malorgio, G. Empirical approach to the sequential relationship between generation, relational capital and performance in family wineries in Spain. International Journal of Wine Business Research, 33, 1 (2021)

18. Delmas, M.A., Gergaud, O. Sustainable Certification for Future Generations: The Case of Family Business. Family Business Review, 27, 228-243 (2014)

19. Vrontis, V., Bresciani, S., Giacosa, E. Tradition and innovation in Italian wine family businesses. British Food Journal, 118, 1883-1897 (2016)

20. Atkin, T., Garcia, R., Lockshin, L. A multinational study of the diffusion of a discontinuous innovation, Australasian Marketing Journal, 14, 17-33, (2006)

21. Contò, F., Vrontis, D., Fiore, M. and Thrassou, A., Strengthening regional identities and culture through wine industry cross border collaboration", British Food Journal, 116, 17881807 (2014)

22. Giacosa, E., Giachino, C., Bertoldi, B., Stupino, M., Innovativeness of Ceretto Aziende Vitivinicole: a first investigation into a wine company. International Food and Agribusiness Management Review, 17, 223-236 (2014)

23. Zhou, L., Han, Y, Gou, Ch., Influence of Family Involvement on Family Firm Internationalization: The Moderating Effects of Industrial and Institutional Environments. Sustainability, 11, 5721 (2019)

24. Petlina, A., Koráb, V. The Structure of Family Ties within the Family Wine Trading Business in the Czech Republic. In. Enometrics XXII, Peer-Reviewed Conference Proceedings, 52-58 (2015) 